\title{
MANUFACTURING A SMALL MACHINE TO SUIT TOPPING SUGAR BEET
}

\author{
Tayel,S.A. ${ }^{1}$, M.F.Khairy ${ }^{2}$, O.M.Kamel ${ }^{3}$ and A.S.El-Shazly ${ }^{4}$
}

\section{ABSTRACT}

The experiments are to carried out in Rice Mechanization Center, Meet El-Deeba, Kafr El Sheikh Governorate. Field experiments are to be carried out to evaluate the performance of the manufactured topping unit at the following topper three forward speeds of 1.5, 2.0, and $2.5 \mathrm{~km} / \mathrm{h}$, three topping heights of 2, 4, and 6cm, the clearance can be adjusted between the knife and the feeler.(Level vertical and horizontally), (clearance between knife and feeler wheel), and three sugar beet moisture content of 50.0, 42.0 and $35.0 \%$.

Theoretical field capacity, actual field capacity, field efficiency, fuel consumption, power requirements, energy requirements, topping performance and topping cost operation (transplanter, unit topper and labor costs) product losses cost (losses price) were studied to evaluate topping performance.

\section{INTRODUCTION}

ugar beet is one of the most important crops, not only for sugar production, but also for producing fodder and organic matter for the soil. Over $40 \%$ of the world, sugar production is produced from sugar beet. Egypt produced around one million tons of sugar beet annually. Sugar cane contribute more than 500000 ton and the other 500000 ton is produced from sugar beet. The cultivated area of sugar beet were 248,871 feddans gave 5,138,190 tons sugar beet roots and 2,327,940 tons beet tops (Ibrahim, et. Al. 2010). However the local consumption of sugar was about 1.5 million ton accordingly about a half million ton have to be imported.(Tayel et al., 1988).

Mechanical sugar beet harvesters are not common in Egypt, and manual methods are exhaustive, and impractical.

\section{1-2-.- Fac. of Agric. - Al-Azhar Univ.}

3- Prof. of Agric- Agric. Eng. Res. Inst., Giza.

4- Study graduate- Agric. Eng. Res. Inst., Giza. 
Sugar beet harvesting is carried out in Egypt manually by hand digging, pulling the root out by shovel and hoe, or by using a chisel plow and collecting the roots manually. Large size of work, more time and consequently more cost are required to carry out beet harvesting (topping, lifting and collecting) although simple toppers and lifters are available which may ease the work considerably. The success of sugar beet harvester depend on two main operations, topping the foliage and lifting beets.

\section{REVIEW OF LITERATURE}

Srivastava and Yadav (1979) developed a three - row tractor drawn sugar beet digger and used sweeps as lifting shovels. Spacing between shovels was maintained at $150-200 \mathrm{~mm}$. It was reported that, about 98.8 $\%$ of the roots were at proper moisture content and the damage through cuts to the beets was about $1 \%$.

Culpin (1986) reported that the harvesting equipment of sugar beet has undergone rapid development in many different directions. There are three basic operations to be carried out:
a) Topping
b) Lifting and cleaning and
d) Loading.

In addition, it may be necessary to windrow or to load the tops. Some harvesters top, lift, clean and load a single row. This can be efficient with a one-man tanker machine, but tends to be inefficient where side loading is carried out. With multi-row harvester, the rate of work can be high, and side loading can work well. He also added that a two-row tanker and a three-row sid loading systems suit many users.

Younis (1987) indicated that the increase of forward speed from 2.36 to $6.54 \mathrm{~km} / \mathrm{h}$ increases the percent of skinned potatoes from 6.33 to $9.97 \%$ while, the damage increases from 9.75 to $18.77 \%$.

Allam et al. (1988) found that mechanical harvesting resulted in drastic reduction of $86 \%$ in labor requirement per ton of harvested beet and up to $69 \%$ of cost harvest. Mechanical harvesting cost is only $33 \%$ of manual harvesting due to reduced labor force from 30 man-day/fed. To 4 manday/fed. The labor requirement per ton of harvested is 1.7, 1.4, 0.8 and 24 man-day for manual digging, tractor -chisel plough, digger, and combine, respectively. 
Tayel (1990) listed the mass characteristics of sugar beet plants are listed in Table 1. The Table showed the mean values of each plot for roots, tops, leaves and total weight.

Table 1: The mean mass characteristics of sugar beet.

\begin{tabular}{|c|c|c|c|c|c|}
\hline Plot No. & $\begin{array}{c}\text { Root } \\
\text { mass, } \mathbf{g}\end{array}$ & $\begin{array}{l}\text { Top } \\
\text { mass, } \mathbf{g}\end{array}$ & $\begin{array}{c}\text { Leaves } \\
\text { mass, } \mathbf{g}\end{array}$ & $\begin{array}{c}\text { Total, } \\
\mathbf{g}\end{array}$ & $\begin{array}{c}\text { Root/Total, } \\
\mathbf{\%}\end{array}$ \\
\hline $\mathbf{1}$ & 1168.54 & 141.88 & 622.42 & 1932.84 & 60.45 \\
\hline $\mathbf{2}$ & 812.67 & 85.82 & 497.48 & 1395.97 & 58.21 \\
\hline $\mathbf{3}$ & 1131.25 & 139.47 & 512.00 & 1782.72 & 63.45 \\
\hline $\mathbf{4}$ & 615.94 & 76.29 & 401.53 & 1093.76 & 56.31 \\
\hline
\end{tabular}

And the root bulk density and moisture content were measured and the results are listed in Table 2.

Zaalouk (1994) modified the 7- blades chisel plow and design of such fork lifter to be used with the chisel 9-plow for sugar beet harvesting. The result indicated that the performance of the designed fork lifter was satisfactory in general, since the average of damage were $4.21 \%$ and $3.6 \%$ with and without topping respectively. The average of unlifted roots were $6.70 \%$ and $8.6 \%$ with and without topping respectively.

Visvanathan et al. (1996) determined the optimum values of cutting velocity, knife bevel angle and shear angle (angle of cut with respect to longitudinal axis of tubers). The results suggested that the specific cutting energy of the tuber (cutting energy per unit area of cut ) was minimum for cutting velocities in the region of $2.5 \mathrm{~m} / \mathrm{s}$, shear angles of 1.05 to 1.31 rad. (60 to 75 deg.) and bevel angles of 0.52 to $0.79 \mathrm{rad}$. (30 to $45 \mathrm{deg}$.).

Awad (2006) developed a sugar beet harvester machine to perform four subsequence functions; a) losing the ridge around the growing roots, b) puling the bulk of leaf cervixes to lift the roots from the ridge with its leafs and vines, c) topping sugar beet plant, and then d) directing the roots back to the ground to be picked up by hand, or transferring them into some container such as trailer.

El-Khateeb and Awad (2006) evaluate a sugar beet topping machine. The results showed that by increasing the forward speed from (1.8 to 5.0 $\mathrm{Km} / \mathrm{h}$ ) tends to increase the over topping from (2.50 to $3.0 \%$ ), under topping (2.40 to $4.20 \%$ ), untopped (2.60 to $4.0 \%$ ), broken beet (6.50 to $9.90 \%)$, effective filed capacity $(2 . .40$ to $3.80 \mathrm{fed} / \mathrm{h})$ and power requirements ( 14.5 to $18.0 \mathrm{~kW})$. 
El-Bialee (2009) resulted that using developed harvester drastic reduction of $65.32 \%$ from total harvesting cost compared with manual harvesting cost. He also added that internal rate of return was $26 \%$ when using developed harvester at speed ratio 10.29.

Ibrahim, et al. (2010) develop a topping unit attached to potato harvester for harvesting sugar beet. They found that both forward speed and knife speed resulted in increasing overtopping, undertopping and untopped beet, $\%$, respectively in all treatments. Results showed that share tilt angle of 25 degree and topping knife speed of $5.9 \mathrm{~m} / \mathrm{s}$ with forward speed of $1.8 \mathrm{~km} / \mathrm{h}$ under moisture content of $18.4 \%$ were the desirable results for all test factors and the total cost.

Therefore, the main objectives of the present study is to construction suitable a topper unit for topping sugar beet crops using the power unit of the prime mover of Yanmar ARP-8 Rice Transplanter to meet the demands of small and medium farmers in Egypt .

\section{MATERIALS AND METHODS}

The main purpose of this research is to construct and evaluate of topper unit using the power unit of the prime mover of Yanmar ARP-8 Rice Transplanter Fig.1.

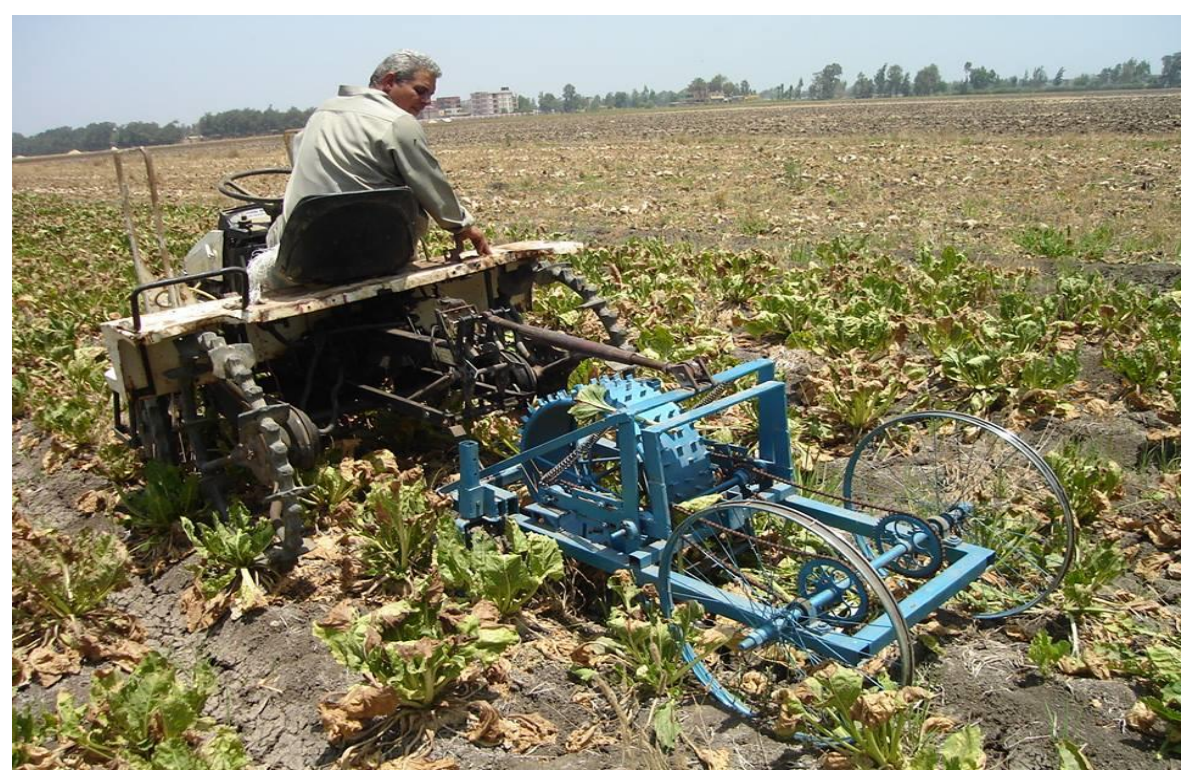

Fig.1: Prime mover of Yanmar ARP-8 Rice Transplanter and topper unit during operation. 
To meet the demands of small and medium farmers in Egypt to topping sugar beet crop. On the other hand, the use of a Rice Transplanter as a source of power. However, the seedling trays of transplanter was separated and the transplanter equipped with topper unit to realizing the goal of intensification use of farm machinery. The field experiments were carried out at Rice Mechanization Center, Meet El-Dyba, Kafr ElSheikh, Governorate. It was planted by the mechanical seeding in an area of about 1.5 feddans during the winter season of 2011/ 2012.

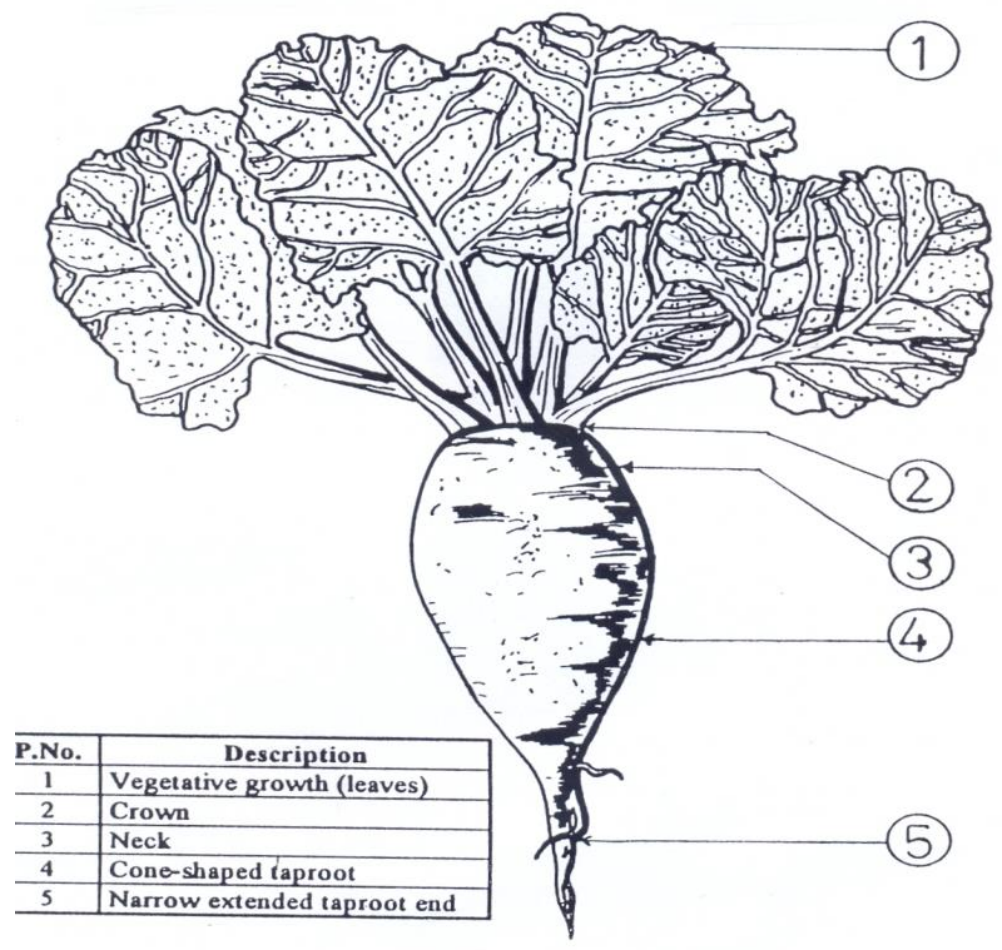

Fig.2: Sugar beet plant (Beta vulgaris L.).

The fertilizing, irrigation and spraying treats were done according to the recommendations of Agriculture Research Center.

Sugar beet is considered a perennial plant, and it consists of the following two main parts, Fig.2.

1) The root system which consists of the crown, the neck, the cone shaped taproot and its narrow extended taproot end. 
2) The vegetative growth, which consists of the leaves.

To carry out this study, three stages of work and tests has been done as follows: -

First: Studding the pervious review of literature and theoretical consideration to decide the main factors and design parameters affecting on the performance of topper unit also to determined the design dimension of topper unit.

Second: Fabricating and manufacturing of topper part and assembling the prototype of topper unit workshop.

Third: Carrying out the final experimental work to test and evaluate the prototype of topper unit under the different variables was proposed in the study scheme.

\subsection{Materials:-}

The materials and equipment used in this study may be indicated as follows: -

The power source unit was used without any modification in forward and rotational speeds and lifting device. The topper unit was mounted behind of the power unit on the frame of iron.

\section{The components of the manufacturing topper unit:}

During developing and manufacturing the topping unit Fig. 3 many points were taken into consideration as the simplicity and cheapness of the topping unit Its simple in use, easy to assembling and disassembling, the least amount of repair required and easy to adjust the topper unit.

Fabricating of machine and preliminary test were carried out at the Rice Mechanization Center workshop, Meet El-Dyba, Kafr El-Sheikh, Governorate.

\section{Frame :-}

The frame is made of flat iron. Pivot made to ease the vertical movement of the feeler the machine length $139 \mathrm{~cm}$ - the machine height $77 \mathrm{~cm}$ - the machine width $75 \mathrm{~cm}$. 

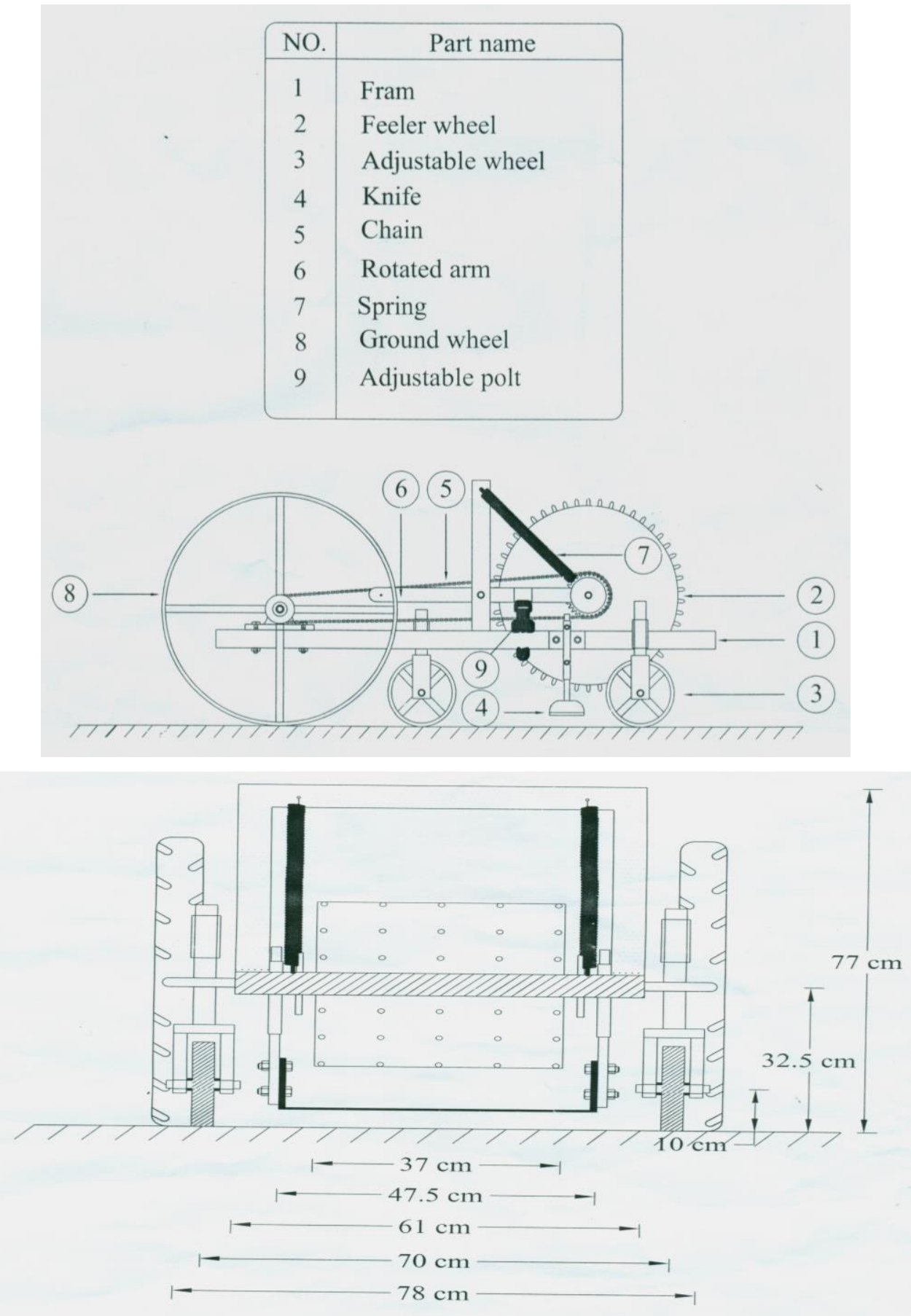

Fig. 3: The main components of the manufacturing topping unit. And Elevation of manufacturing topping unit. 


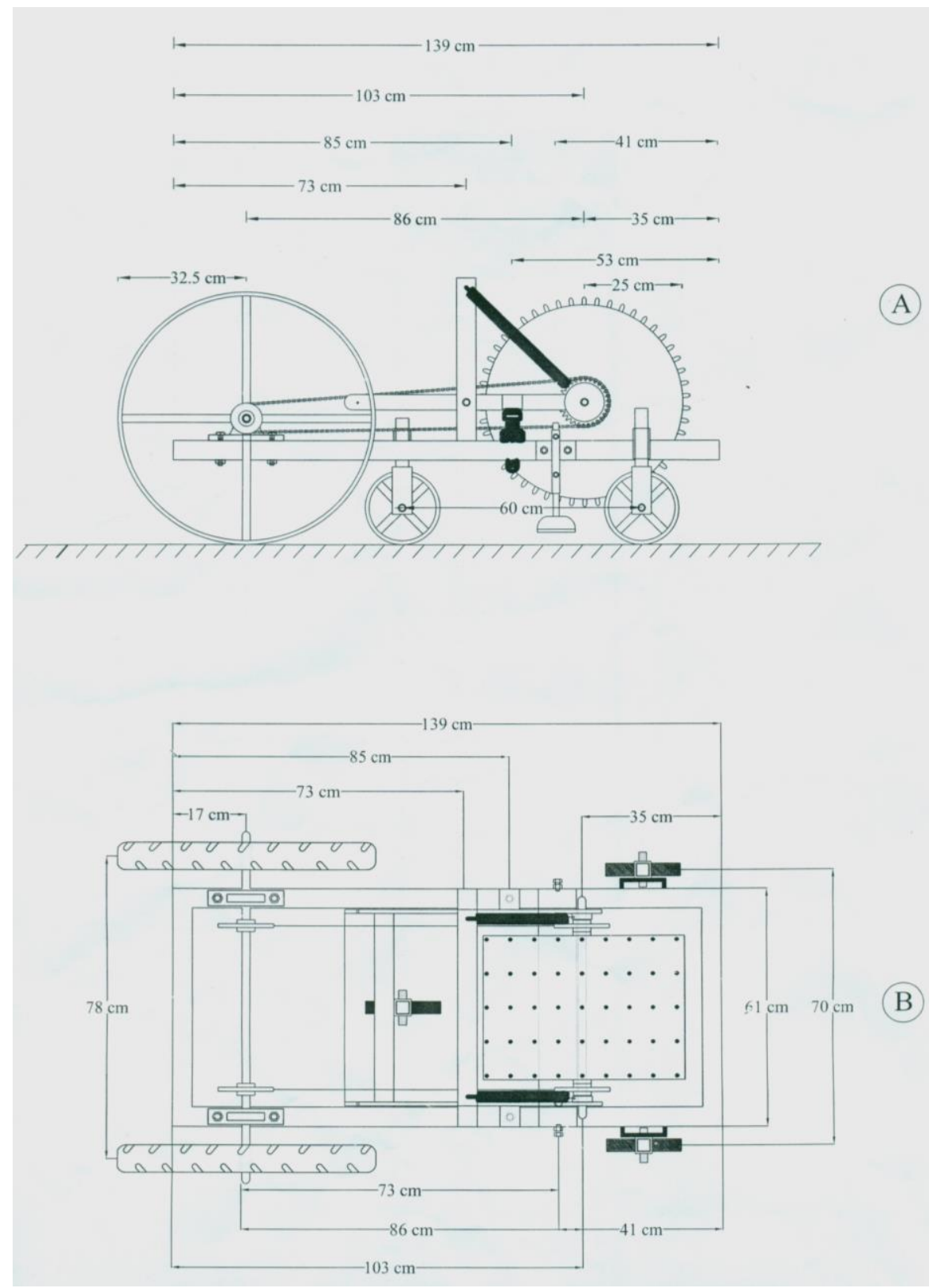

Fig. 4: Side view (A) and plane view (B) dimensions of the construct topping unit.

\section{Knife :-}

The straight knife was formed from flat iron (steel). It has the dimensions of $47.5 \mathrm{~cm}$ long x $0.5 \mathrm{~cm}$ thick. The knife can be easily bolted from the end on connected arm, it can slide easily up and down, also, forward and 
backward leading the knife, so that, the clearance can be adjusted between the knife and the feeler.(Level vertical and horizontally)

\section{Feeler wheel :-}

The feeler wheel is $50 \mathrm{~cm}$ diameter and $37 \mathrm{~cm}$ width which were mounted on $2.5 \mathrm{~cm}$ diameter threaded shaft and $6 \mathrm{~cm}$ clearance between knife and feeler wheel. The wheel is fabricated from flat iron (steel), thick $1 \mathrm{~cm}$ was formed to be rough gear teeth shape with $0.4 \mathrm{~cm}$ height and $0.5 \mathrm{~cm}$ pitch of teeth. as shown in Fig.3, and 4, and 70 finger fixed by welding around feeler wheel and $4 \mathrm{~cm}$ length to avoid slippage during moving around beet top. Feeler shaft connected rod was pulled through the machine frame by using compressing spring with $30 \mathrm{~cm}$ length as shown in the same figure.

\section{Drive system :-}

The machine was designed, so that, the feeler may take its motion from the ground wheel with $70 \mathrm{~cm}$ diameter and distance between two ground wheel $78 \mathrm{~cm}$ where there was an sprocket fixed in the main shaft of ground wheel and the other sprocket was fitted to the shaft of the feeler as shown in Figs.3 and 4.The power is transmitted between them by using drive chine with length $86 \mathrm{~cm}$.

The modern beet harvester is fitted with a topping mechanism which, if correctly set, will satisfactorily top the beet. Fig.3 shows a typical arrangement of the drive and topping mechanism. It is important for this mechanism to be adjust correctly and there are a number of steps that can be made : Firstly, when the harvester starts work the wheels will be between rows of beet and the feeler wheel should be positioned centrally over the crown of the beet. There will be provision on the harvester to allow for lateral adjustment of the feeler wheel. Secondly, the whole feeler wheel unit, and knife, are fixed with a tension spring which allows the unit to float. Adjustment the tension of this spring gave the effect of the feeler wheel ride being heavily or lightly on the beet crop, the adjustment must be made to suit beet conditions, bearing in mind that if the beet tops are bulky the tension on the spring should be reduced so that more weight of the feeler wheel is on the top of the beet. This is necessary because the wheel helps to hold the beet in position whilst the knife cuts through the crown. The tension should be increased if the tops are light but at all times the feeler wheel must be allowed to float so that it can rise and fall to suit the various heights of the beet. Thirdly, the 
position of the knife in relation to the feeler wheel determines how the beet will be topped and how much crown will be removed. The knife can be raised or lowered but its final work position will depend on the conditions of the beet. As a general guide a clearance of between knife and feeler wheel 10 to $80 \mathrm{~mm}$ will be a reasonable setting to start with, see Fig.3 .

\section{Methods and Measurements:}

\section{Experimental procedure:}

This research has been carried out in the research farm of R.M.C., Meet El-Dyba, Kafr El-Sheikh, Governorate during winter season of 2011/2012 in order to evaluate performance quality of topping sugar beet depending on the real requirements of the Egyptian farmer and manufacture and to study the effect of forward speeds of 1.5, 2.0, and $2.5 \mathrm{~km} / \mathrm{h}$, topping heights of $2.0,4.0$, and $6.0 \mathrm{~cm}$ (clearance between knife and feeler wheel), and sugar beet moisture content 35.0, 42.0, and 50.0 $\%$ were used.

\section{Measurement related to topper machine :}

\section{Topper performance:}

Twenty plants of sugar beet were lifted by hand digging from every treatment and cleaned from the soil clods before harvesting operation to measure important beet properties.

In field experiments with sugar beet topper, correct topped beet, under topped beet, overtopped beet, untopped beet, broken beet and topping efficiency were assessed as percent to be indicator for the topper unit performance.

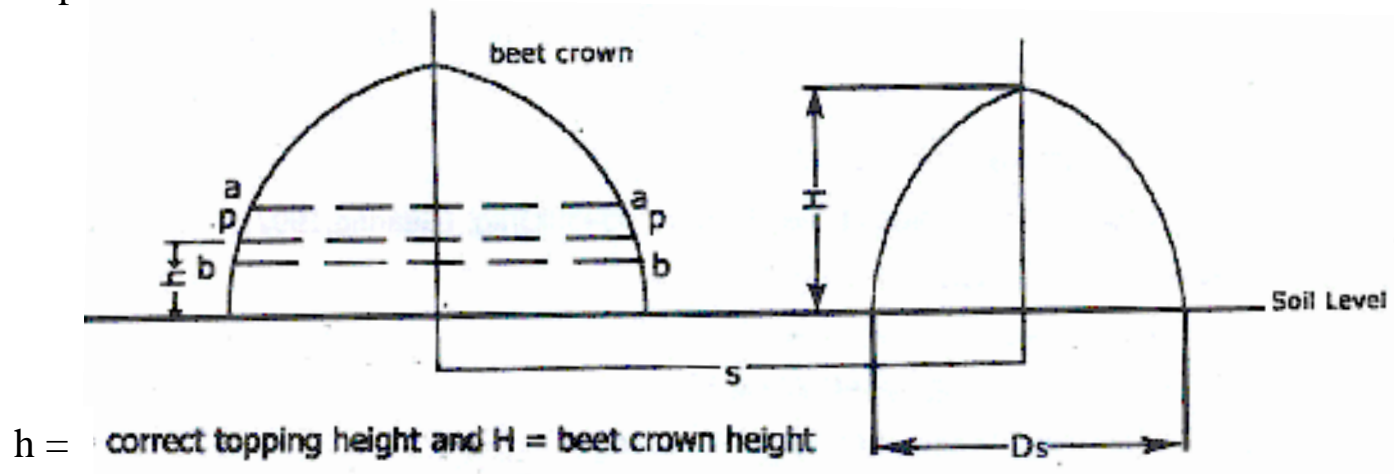

Fig.5: Critical parameters of a beet crown stand showing correct topping plane (P-P), the plane for an undertopped crown (a-a) and an overtopped crown (b-b). 
A beet is shown at Fig.5 with the correct topping plane drawn on the assumption that the beet is horizontal and just below the lowest leaf scar. If the cut was made in the plane (p-p), the beet will be correctly topped, if the beet was cut in the plane (a-a), the beet will be under topped and if it was cut at the plane (b-b), it will be overtopped. During the experimental work, the performance of topper assessed by taking randomly selected $30 \mathrm{~m}$ of work length, lifting the beet and collecting the tops. So under or overtopped can be estimated easily.

During the experimental work, the performance of topping unit assessed by, lifting the beet and collecting the tops. The percentage of the items which are used to control topper performance, can be calculated by using the following equations:

Correct topped beet $(\%)=\frac{\text { Correcttopped beet }}{\text { Topped beet }} \times 100$

Over topped beet $(\%)=\frac{\text { Overtopped beet }}{\text { Topped beet }} \times 100$

Under topped beet $(\%)=\frac{\text { Undertopped beet }}{\text { Topped beet }} \times 100$

Untopped beet $(\%) \quad=\frac{\text { Untopped beet }}{\text { Topped beet }} \times 100$

Broken beet $(\%)=\frac{\text { Broken beet }}{\text { Total beet }} \times 100$

Topping efficiency $(\%)=\frac{\text { Topped beet }}{\text { Total beet }} \times 100$

\section{Field capacity:}

\section{a) Theoretical field capacity ( $\left.\mathbf{R}_{\text {th }}\right)$ :}

Was calculated by using the following formula:

$\mathbf{R}_{\text {th }}=\mathrm{Vx} \mathrm{W} / 4.2$, fed/h

Where:

$\mathrm{V}=$ forward speed, $\mathrm{km} / \mathrm{h}$, and

$\mathrm{W}=$ machine width, $\mathrm{m}$.

b) Effective field capacity ( $\left.\mathbf{R}_{\text {act }}\right)$ :

Was calculated by using the following formula:

$\mathbf{R}_{\text {act }}=(\mathrm{T})^{-1}$, fed $/ \mathrm{h}$. 
Where:

$\mathrm{T}=$ Actual time in hours required per travel, $\mathrm{h}$.

\section{c) Determination of field efficiency $(\boldsymbol{\eta})$ :}

The field efficiency was calculated by using the following formula:

$\boldsymbol{\eta}=\mathrm{R}_{\text {act }} / \mathrm{R}_{\text {th }} \times 100, \%$

Where:

$\mathbf{R}_{\text {act }}=$ actual field capacity, fed $/ \mathrm{h}$, and

$\mathbf{R}_{\text {th }}=$ theoretical field capacity, fed

Power consumption, kW,(EP):

Estimation of the required engine power for the transplanter mounted topper unit were carried out by accurately measuring the decrease in fuel level in the fuel apparatus. The following formula was used to estimate the engine power, (Suliman et al., 1983).

$$
\mathrm{EP}=\frac{\mathrm{F} . \mathrm{C} \times \rho_{\mathrm{r}} \times \mathrm{L} . \mathrm{C} . \mathrm{V} \times 427 \times \eta_{\mathrm{m}} \times \eta_{\mathrm{th}}}{3600 \times 75 \times 1.36}, \mathrm{~kW}
$$

Where:

$\mathrm{Fc}=$ Fuel consumption, $\mathrm{L} / \mathrm{h}$,

l.c.v. = Lower calorific value of fuel $(11030 \mathrm{kcal} / \mathrm{kg}$ for gasoline fuel $)$,

$\mathrm{p}_{\mathrm{f}}=$ Density of the fuel $(0.73 \mathrm{~kg} / \mathrm{l}$ for gasoline fuel $)$,

$427=$ Thermal-mechanical equivalent, $\mathrm{kg} \cdot \mathrm{m} / \mathrm{k}$ cal;

$\dot{\eta}_{\mathrm{th}}=$ Thermal efficiency of engine ( $35 \%$ for gasoline engine), and

$\dot{\eta}_{\mathrm{m}}=$ Mechanical efficiency of engine (80\% for gasoline engine).

\section{Energy requirement:}

Energy required for operating the topping machine was calculated according to the following equation: -

Energy requirements $=\frac{\text { Powercon } \text { suption }, k w}{\text { Actualfieldcapacity, fed } / h}, k w \cdot h / f e d$

\section{Cost analysis:}

Machinery costs, which include fixed cost (depreciation, interest, housing, insurance and taxes) and variable costs (repair and maintenance, 
fuel, oil and labor) are a major capital input for most farmers. The methodology of estimating topping costs $(\mathrm{LE} / \mathrm{h})$ or (LE/fed) was as follow (Hunt,1983).

\section{Fixed costs:}

- Depreciation $=\frac{\text { Original } \cos t-\text { Salvagevalue }}{\text { Machinelife }}, L E /$ year

Salvage value is $10 \%$ of original cost.

$$
\text { Taxes, shelter, insuranceand int erest }=\frac{\text { Original } \cos t}{\text { Machinelife }} \times 4 \%, L E / h
$$

\section{Variable costs:}

$$
\text { Maint enanceandrepair } \cos t=\frac{\text { Original } \cos t}{\text { Annualoperatinglife }} \times 4.5 \%, L E / h
$$

$$
\text { Laborsalary }=\frac{\text { Salary }}{\text { Operatinghours }}, L E / h
$$

Fuel price $=\mathrm{LE} / \mathrm{L}$

Oil and lubrication $=\mathrm{LE} / \mathrm{L}$

\section{Then:}

Total cost $(\mathrm{LE} / \mathrm{h})=$ Fixed cost $(\mathrm{LE} / \mathrm{h})+$ Variable cost $(\mathrm{LE} / \mathrm{h}) \ldots . . .(12)$

$$
\text { Total } \cos t(L E / f e d)=\frac{\text { Total } \cos t(L E / h)}{\text { Effectivefieldcapacity }(\text { fed } / h)}, L E / \text { fed }
$$

\section{RESULTS AND DISCUSSION}

The experiments were classified into two main parts. The first part includes manufacturing and testing the performance of unit topper. While, the second part contained evaluating the topping accuracy of unit topper under Egyptian conditions.

\section{Machine performance:}

\section{Topping operation:}

Values of topping efficiency, under topped, correct topped, over topped, untopped beet and broken beet were calculated. 


\section{a) Overtopping:}

Fig.6 illustrate the effect of forward speed, sugar beet moisture content and topping heights on overtopping \%. It can be noticed that increasing the forward speed from 1.5 to $2.5 \mathrm{~km} / \mathrm{h}$ tends to increase overtopping percentage from 2.9 to $3.22 \%$ at sugar beet moisture content of $50.0 \%$ and topping height $2 \mathrm{~cm}$, respectively. These trends may be due to the difficulty of keeping topping knife adjusted at a constant height during high speeds.

In the same manner, the same increment of the topping heights from 2 to $6 \mathrm{~cm}$ tends to increase overtopping from 2.50 to $3.22 \%$ at forward speed of $2.5 \mathrm{~km} / \mathrm{h}$ and sugar beet moisture content of $50.0 \%$, respectively.

Generally, the percentage of over topped beet is directly proportional to forward speed. Similar results have been obtained by El-Khateeb and Awad, 2006.

\section{b) Under topping:}

Fig.7 show the effect of forward speed, sugar beet moisture content and topping heights on undertopping $\%$. It can be said that increasing the forward speed from 1.5 to $2.5 \mathrm{~km} / \mathrm{h}$ tends to increase undertopping beet percentage from 2.82 to $4.02 \%$ at sugar beet moisture content of $50.0 \%$ and topping height $2 \mathrm{~cm}$, respectively. These trends may be due to the difficulty of keeping topping knife adjusted at a constant height during high speeds.

Meanwhile, the same increment of the topping heights from 2 to $6 \mathrm{~cm}$ tends to decrease undertopping beet from 4.02 to $2.60 \%$ at forward speed of $2.5 \mathrm{~km} / \mathrm{h}$ and sugar beet moisture content of $50.0 \%$, respectively.

Generally, the percentage of undertopped beet is directly proportional to forward speed. Similar results have been obtained by El-Khateeb and Awad, 2006.

\section{c) Untopped beet}

Fig.8 illustrate the effect of forward speed, sugar beet moisture content and topping heights on untopped beet \%. They indicated that by increasing the forward speed from 1.5 to $2.5 \mathrm{~km} / \mathrm{h}$ tends to increase untopped beet percentage from 3.71 to $4.26 \%$ at sugar beet moisture content of $50.0 \%$ and topping height $2 \mathrm{~cm}$, respectively. 
Sugar beet moisture content $(\%)$
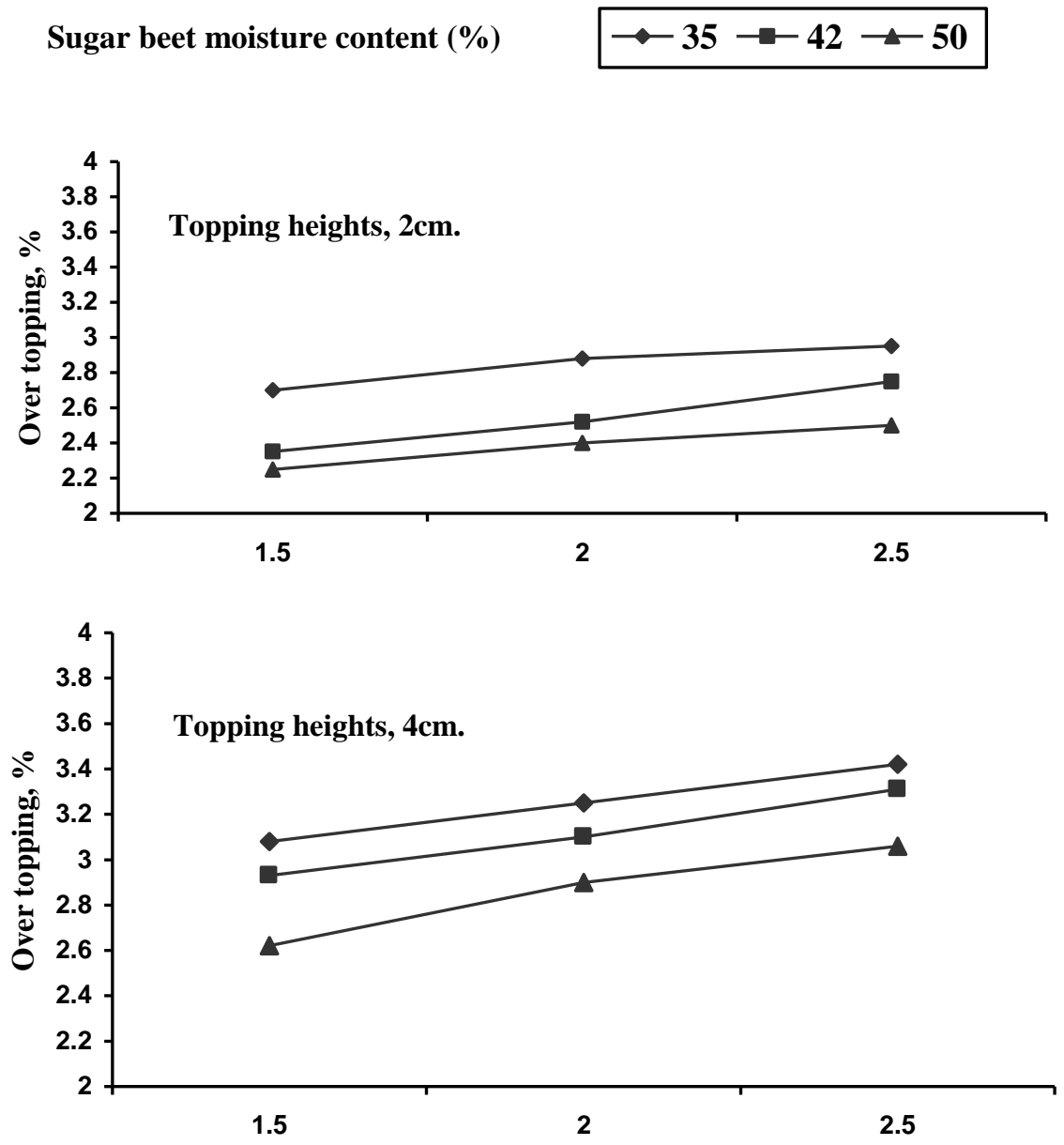

Topping heights, $3 \mathrm{~cm}$.

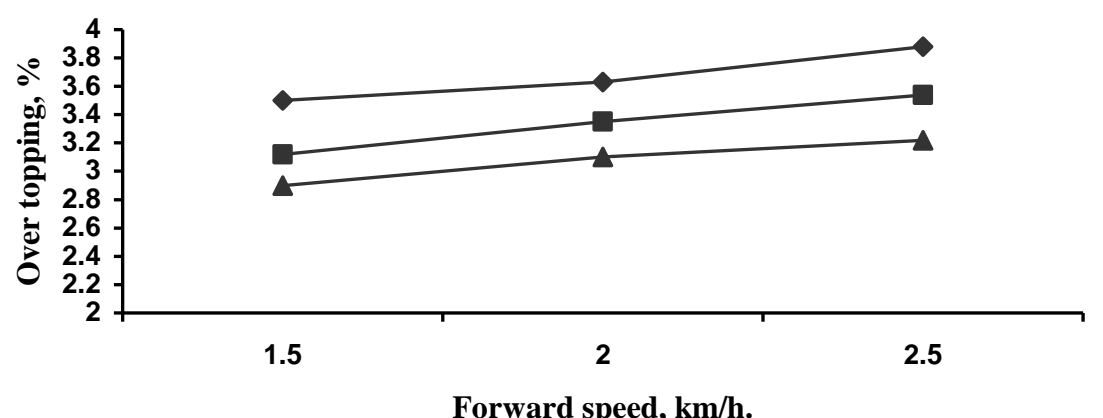

Fig.6: Effect of forward speed and sugar beet moisture content on over topping beet percentage at topping heights 2,4 and $6 \mathrm{~cm}$. 
On the other hand, the same increment of the topping heights from 2 to $6 \mathrm{~cm}$ tends to decrease untopped beet from 3.71 to $2.77 \%$ at forward speed of $1.5 \mathrm{~km} / \mathrm{h}$ and sugar beet moisture content of $50.0 \%$, respectively. Generally, the percentage of untopped beet is directly proportional to forward speed. Similar results have been obtained by Mohamed, 1998 and El-Bialee, 2009.

\section{d) Correct topped beet:}

Fig.9 illustrate the effect of forward speed, sugar beet moisture content and topping heights on correct topped beet \%. It can be noticed that increasing the forward speed from 1.5 to $2.5 \mathrm{~km} / \mathrm{h}$ tends to decrease correct topped beet percentage from 92.00 to $90.39 \%$ at sugar beet moisture content of $35.0 \%$ and topping height $2 \mathrm{~cm}$, respectively. These trends may be due to the difficulty of keeping topping knife adjusted at a constant height during high speeds.

Meanwhile, the topping height of $4 \mathrm{~cm}$ recorded the highest values correct topped beet percentage which were 95.91, 95.00 and $93.50 \%$ at forward speed of $1.5 \mathrm{~km} / \mathrm{h}$, followed topping height 2 , and $6 \mathrm{~cm}$, respectively.

Generally, the percentage of correct topped beet is inversely proportional to forward speed. Similar results have been obtained by El-Bialee, 2009.

\section{e) Topping efficiency:}

The percentage of topping efficiency is related to the percentage of untopped beet, which the percentage of untopped beet increased by increased the forward speed. The percentage of topping efficiency decreased by increasing the forward speed.

Fig.10 summarize the effect of forward speed, sugar beet moisture content and topping heights on topping efficiency \%. It could be realized that increasing the forward speed from 1.5 to $2.5 \mathrm{~km} / \mathrm{h}$ tends to decrease the topping efficiency percentage from 96.29 to $95.74 \%$ at sugar beet moisture content of $50.0 \%$ and topping height $2 \mathrm{~cm}$, respectively.

On the other hand, by increasing of the topping heights from 2 to $6 \mathrm{~cm}$ tends to increase topping efficiency from 96.29 to $97.23 \%$ at forward speed of $1.5 \mathrm{~km} / \mathrm{h}$ and sugar beet moisture content of $50.0 \%$, respectively. Generally, the percentage of topping efficiency is inversely proportional to forward speed. Similar results have been obtained by El-Bialee, 2009. 


\section{Sugar beet moisture content $(\%) \quad \square-35 \rightarrow-42 \rightarrow 50$}

Topping heights, $2 \mathrm{~cm}$.

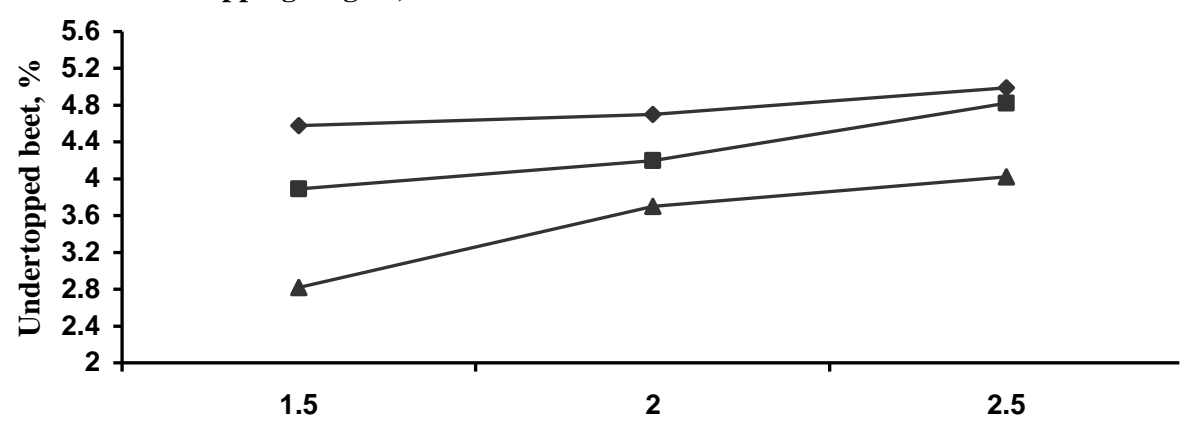

Topping heights, $4 \mathrm{~cm}$.

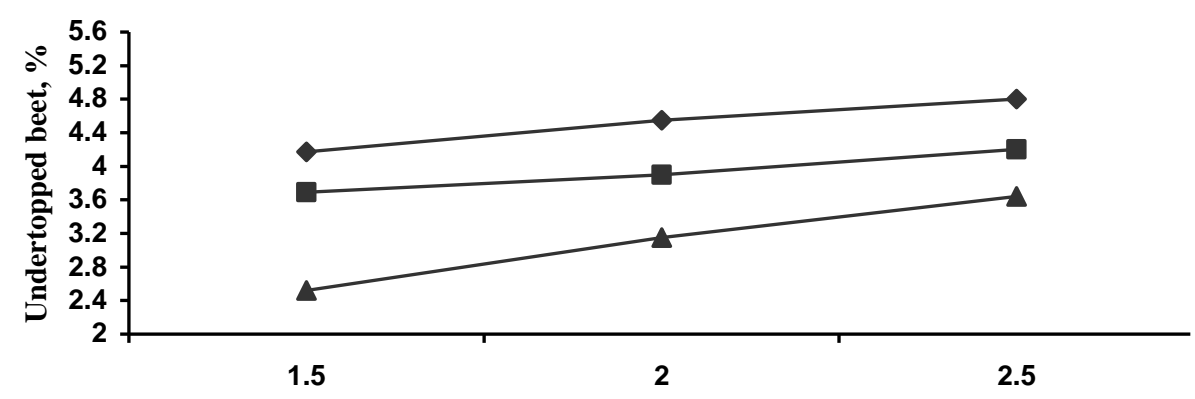

Topping heights, $3 \mathrm{~cm}$.

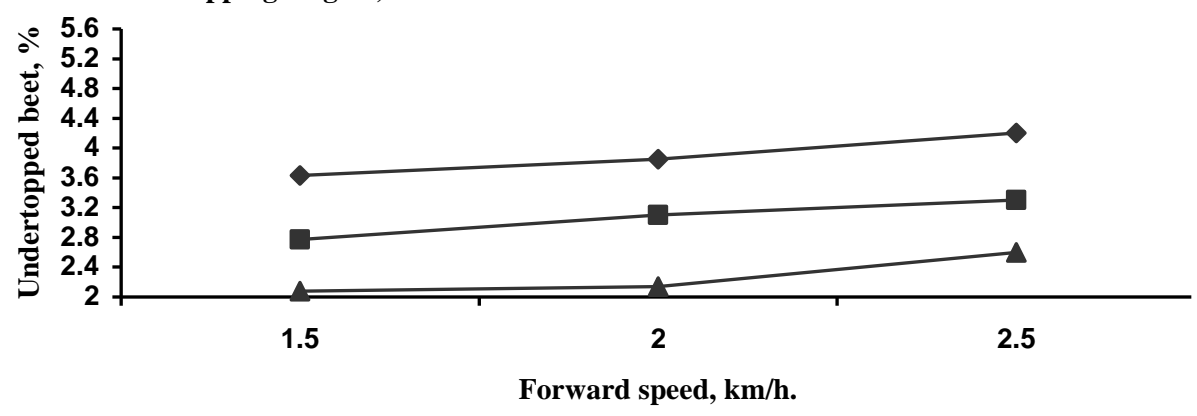

Fig.7.: Effect of forward speed and sugar beet moisture content on Under topped beet percentage at topping heights 2,4 and $6 \mathrm{~cm}$. 


\section{Sugar beet moisture content $(\%) \quad \rightarrow-35 \rightarrow-42 \rightarrow 50$}

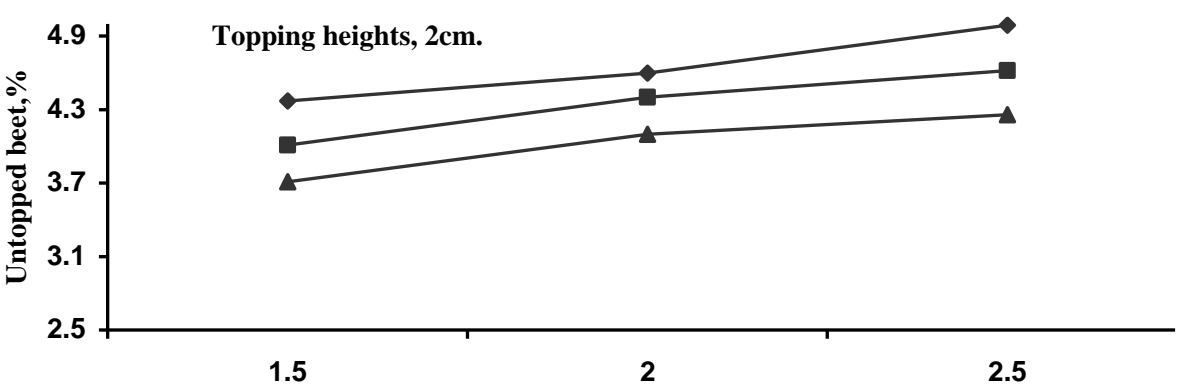

Topping heights, $2 \mathrm{~cm}$.

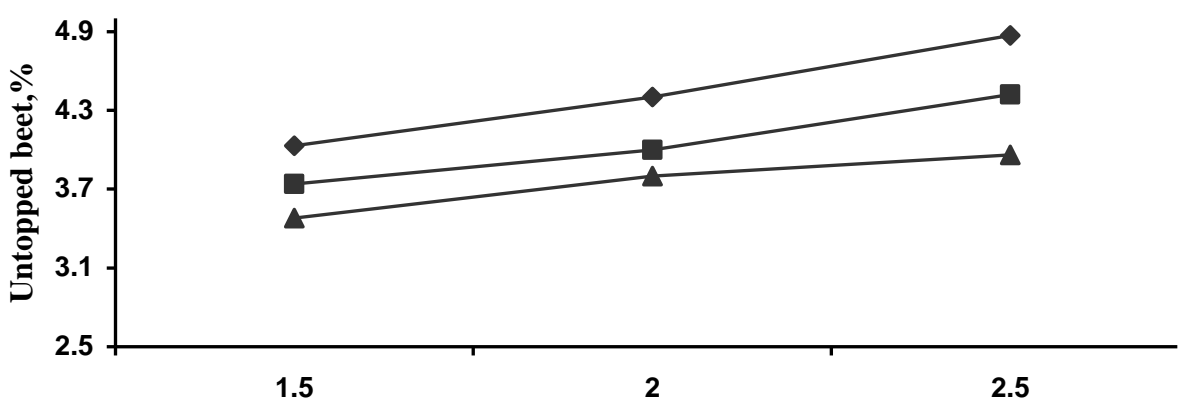

Topping heights, $3 \mathrm{~cm}$.

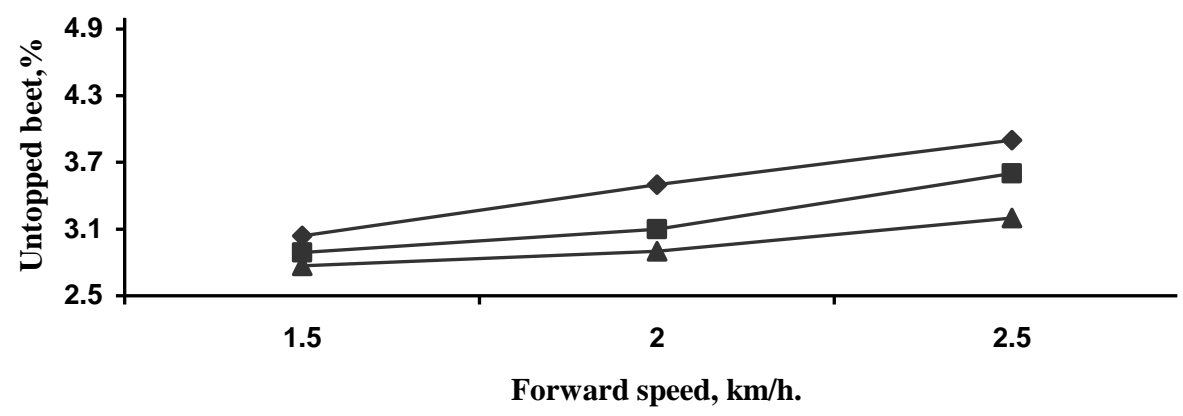

Fig.8: Effect of forward speed and sugar beet moisture content on Untopped beet percentage at topping heights 2,4 and $6 \mathrm{~cm} \mathbf{~ c m}$. 


\section{Sugar beet moisture content $(\%) \quad \rightarrow-35 \rightarrow-42 \rightarrow 50$}

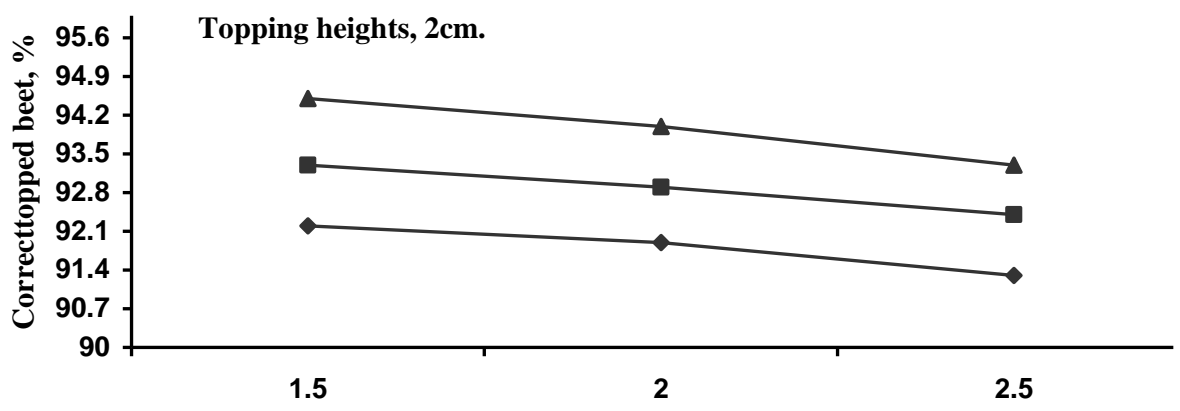

Topping heights, $4 \mathrm{~cm}$.

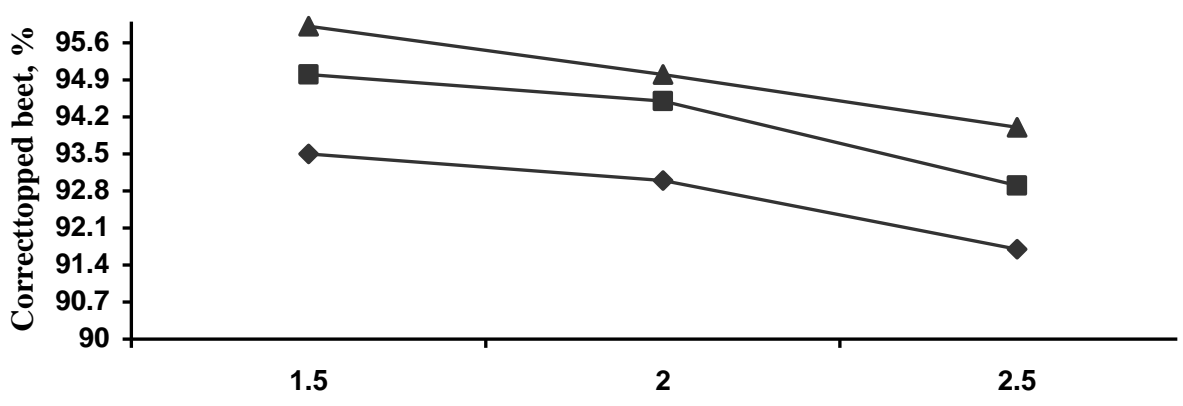

Topping heights, $3 \mathrm{~cm}$.

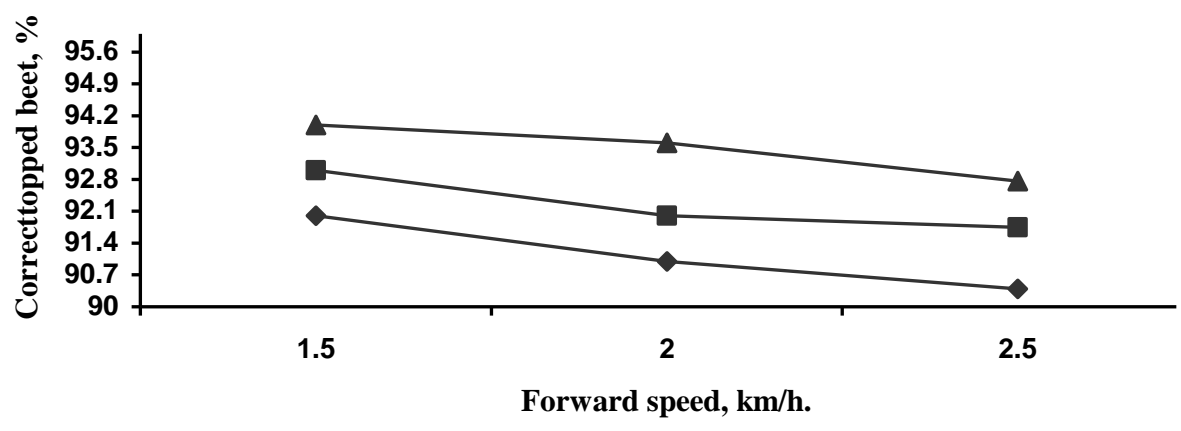

Fig.9: Effect of forward speed and sugar beet moisture content on Correcttopped beet percentage at topping heights 2,4 and $6 \mathrm{~cm}$. 
Sugar beet moisture content (\%)

$$
\multimap 35 \rightarrow-42 \multimap 50
$$

Topping heights, $1 \mathrm{~cm}$.

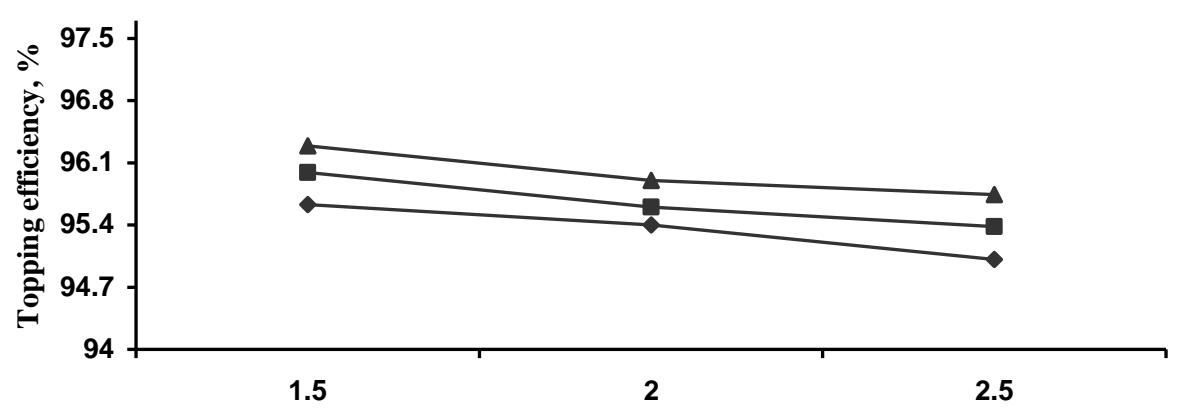

Topping heights, $2 \mathrm{~cm}$.

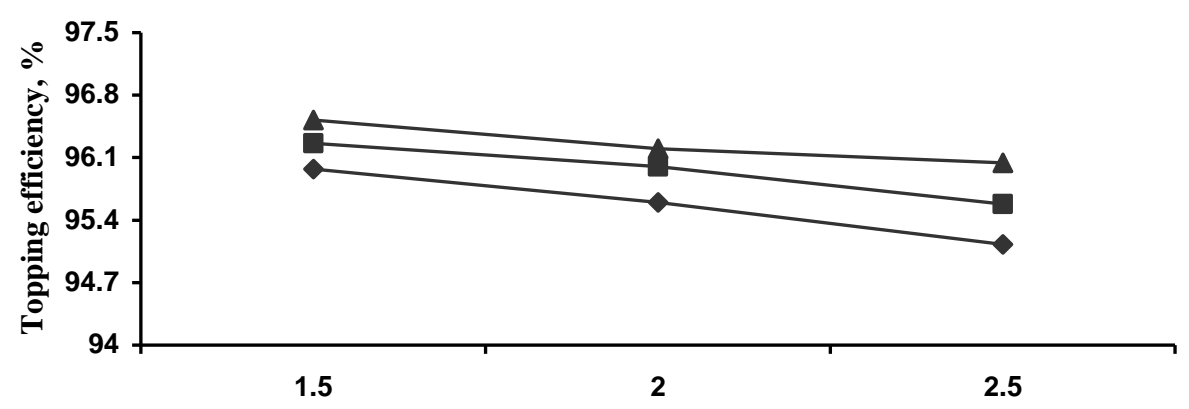

Topping heights, $3 \mathrm{~cm}$.

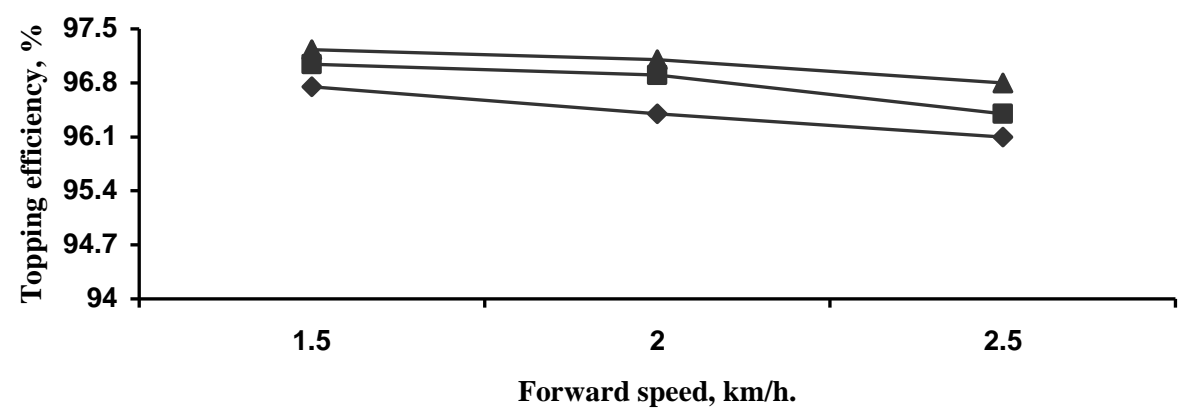

Fig.10: Effect of forward speed and sugar beet moisture content on topping efficiency percentage at topping heights 2,4 and $6 \mathrm{~cm}$. 
The maximum topping efficiency of $97.23 \%$ was recorded at topping height $6 \mathrm{~cm}$, sugar beet moisture content of $50.0 \%$ and forward speed of $1.5 \mathrm{~km} / \mathrm{h}$. The minimum topping efficiency of $95.01 \%$ was recorded at topping height $2 \mathrm{~cm}$, sugar beet moisture content of $35.0 \%$ and forward speed of $2.5 \mathrm{~km} / \mathrm{h}$.

\section{Field capacity and efficiency:}

By increasing forward speed from 1.5 to $2.5 \mathrm{~km} / \mathrm{h}$ tends to increase the theoretical field capacity from 0.4 to $0.86 \mathrm{fed} / \mathrm{h}$, and actual field capacity from 0.26 to $0.75 \mathrm{fed} / \mathrm{h}$.

Also, by increasing the forward speed, increase the field efficiency. This results due to increase the forward speed decrease the effective time and increasing the actual field capacity.

Table 3: The relationship between forward speed, and theoretical field capacity, actual field capacity, field efficiency, slip ratio, energy requirements and topping cost at topping height $6 \mathrm{~cm}$ and sugar beet moisture content of $50 \%$.

\begin{tabular}{|c|c|c|c|}
\hline (F.S) $\mathbf{~ k m} / \mathbf{h}$ & $\mathbf{1 . 5}$ & $\mathbf{2 . 0}$ & $\mathbf{2 . 5}$ \\
\hline (T.F.C) fed/h & 0.4 & 0.53 & 0.86 \\
\hline (A.F.C) fed/h & 0.26 & 0.45 & 0.75 \\
\hline (F.E) \% & 65.00 & 84.91 & 87.21 \\
\hline ( T.E) \% & 97.23 & 97.10 & 96.80 \\
\hline (S.R) \% & 4.0 & 5.5 & 7.9 \\
\hline (E.R) kW.h/fed & 9.24 & 9.12 & 8.62 \\
\hline (T.C) LE/fed. & 79.4 & 45.9 & 27.5 \\
\hline
\end{tabular}

By increasing the forward speed from 1.5 to $2.5 \mathrm{~km} / \mathrm{h}$, the field efficiency increased from 65 to $87.21 \%$.

\section{Slip ratio, S.R.(\%):}

By increasing topper machine forward speed from 1.5 to $2.5 \mathrm{~km} / \mathrm{h}$ tends to increased the slip from 4.0 to $7.9 \%$ as shown in Table 3 . This is due to increase of the soil resistance. This agrees well with (Kamel and ElKhateeb, 2002).

\section{Energy required( E.R):}

Table 3 clearly indicates the decrease of total energy required kW.h/fed by increasing forward speed. This results due to decrease the affective time and increase the actual field capacity. 
By increasing the forward speed from 1.5 to $2.5 \mathrm{~km} / \mathrm{h}$ tends to decrease energy required from 9.24 to $8.62 \mathrm{~kW} . \mathrm{h} / \mathrm{fed}$.

The maximum value of energy required was $9.24 \mathrm{~kW} . \mathrm{h} / \mathrm{fed}$ at forward speed $1.5 \mathrm{~km} / \mathrm{h}$, and minimum energy required were $8.26 \mathrm{~kW} . \mathrm{h} / \mathrm{fed}$ at forward speed $2.5 \mathrm{~km} / \mathrm{h}$.

\section{Cost of topping operation (T.C):}

The results indicated that the total costs for (Transplanter and topper unit) were $20.65 \mathrm{LE} / \mathrm{h}$. While the total costs for topping operation was 79.4 , 45.9 and $27.5 \mathrm{LE} / \mathrm{fed}$, at topping forward speeds $1.5,2.0$ and $2.5 \mathrm{~km} / \mathrm{h}$, respectively.

\section{Cost of manual topping:}

For topping and loading one feddan, 10 labors are used and each labor takes $40 \mathrm{LE}$, so the manual cost of topping and loading one feddan is 400 LE/fed. This result reflects that mechanical topping causes a drastic reduction at topping operation cost.

\section{SUMMARY AND CONCLUSION}

The main results of this study can be summarized in the following points:

(1) By increasing the forward speed from (1.5 to $2.5 \mathrm{~km} / \mathrm{h}$ ) tends to increase overtopping from (2.9 to $3.22 \%$ ), undertopping beet from ( 2.82 to $4.02 \%$ ) and untopped beet from (3.71 to $4.26 \%$ ) at sugar beet moisture content of $50.0 \%$ and topping height $2 \mathrm{~cm}$, respectively. These trends may be due to the difficulty of keeping topping knife adjusted at a constant height during high speeds.

(2) The increasing the forward speed from $(1.5$ to $2.5 \mathrm{~km} / \mathrm{h})$ tends to decrease correct topped beet from (92.00 to $90.39 \%$ ) and topping efficiency from (96.29 to $95.74 \%$ ) at sugar beet moisture content of $50.0 \%$ and topping height $2 \mathrm{~cm}$, respectively.

(3) The maximum topping efficiency of $97.23 \%$ was recorded at topping height $6 \mathrm{~cm}$, sugar beet moisture content of $50.0 \%$ and forward speed of $1.5 \mathrm{~km} / \mathrm{h}$. The minimum topping efficiency of $95.01 \%$ was recorded at topping height $2 \mathrm{~cm}$, sugar beet moisture content of 35.0 $\%$ and forward speed of $2.5 \mathrm{~km} / \mathrm{h}$. 
(4) By increasing forward speed from (1.5 to $2.5 \mathrm{~km} / \mathrm{h}$ ) tends to increase the theoretical field capacity from ( 0.4 to $0.86 \mathrm{fed} / \mathrm{h})$, actual field capacity from $(0.26$ to $0.75 \mathrm{fed} / \mathrm{h}$ ), field efficiency from (65 to $87.21 \%$ ) and slip ratio from (4.0 to 7.9\%), respectively.

(5) By increasing the forward speed from 1.5 to $2.5 \mathrm{~km} / \mathrm{h}$ tends to decrease energy required from $(9.24$ to $8.62 \mathrm{~kW} . \mathrm{h} / \mathrm{fed})$ and topping cost from (79.4, 45.9 and $27.5 \mathrm{LE} / \mathrm{fed})$, respectively. Also, the manual cost of topping and loading one feddan is $400 \mathrm{LE} / \mathrm{fed}$. This result reflects that mechanical topping causes a drastic reduction from total cost of manual topping operation.

\section{REFERENCES}

Allam, A.I.; A.H. Nour and M.A. Farag (1988). Prospective of sugar beet mechanical growing. Agric. Res. Review. Agric. Res. Center, Giza Egypt, 66 (3) : 537-543.

Awad, M.A.(2006). Developing of a pulling out mechanism for harvesting sugar beet crop. Ph.D. Thesis. Agric.Eng.Dept., Fac.Agric., Mansoura Univ: 28-112.

Culpin, C. (1986). Farm machinery. Handbook. $11^{\text {th }}$ ed. AM. Dip. Ag. (Contab.), Flange Collins and Grafton, London, W1: 252-257.

El-Bialee, N.M.Y. (2009). Development of sugar beet harvester to suit Egyptian condition. Ph.D.Thesis, Agric. Mech.Dept., Fac. of Agric. Al-Azhar univ. Cairo.

El-Khateeb,H.A and N.M. Awad (2006). The mechanical performance of sugar beet topper. Egypt J. Agric. Res., 84 (1) : 111-128.

Hunt, D.R. (1983). Farm power and machinery management. Iowa state univ. Press AMES, Iowa, U.S.A.

Ibrahim,M.M.; H.N.Abdel-Mageed and A.E.Khater (2010). Factors affecting on topping efficiency and quality of sugar beet crop. The $5^{\text {th }}$ Arab Mansoura Conference of Food and Dairy Science \& Technology 18-22 October 2010. Mansoura Univ. J. of Agric. Sci., 35 (8) : 810-825. 
Kamel, O. and El-Khateeb, H.A. (2002). Performance evaluation of two different system of rice transplanter under Egyptian conditions. Egypt J.Agric.Res., 80 (3) : 1317-1335.

Srivastava, N.S. and R.M.Yadav (1979). Mechanizing sugar beet cultivation in India. The Agric. Eng. In India, 21: 35-38.

Suliman, A.E.; G.E. Nasr and W.M. Awady (1993).A study an the effect of different systems of tillage on physical properties of the soil.. Misr J. Ag .Eng., 10 (2): 169-189.

Tayel, S.A. (1990). A mechanized sugar beet system for small farms. Final Report National Agric Res. Proj., NARP, Fac. of Agric. AlAzhar Univ., : 76.

Tayel, S.A.; M.F. Wahby and M.F. Khairy (1988). Effect of soil preparation on the physical and mechanical properties of sugar beet. Misr J. Ag .Eng., 5 (3): 357-366.

Visvanthan, R.; V.Sreenayanan and K.R. Swaminathan (1996). Effect of knife angle and velocity on the energy required to cut cassava tubers. J.Agric. Eng.Res., 64 : 99-102.

Younis, S.M. (1987). Mechanization of potato harvesting with minimum losses. Alexandria J. Agric. Res., 32 (3) : 1-10.

Zaalouk, A.K. (1994).Sugar beet harvesting mechanization. M.Sc. Thesis, Fac. of Agric. Agric Eng.Dept. Al-Azhar Univ.

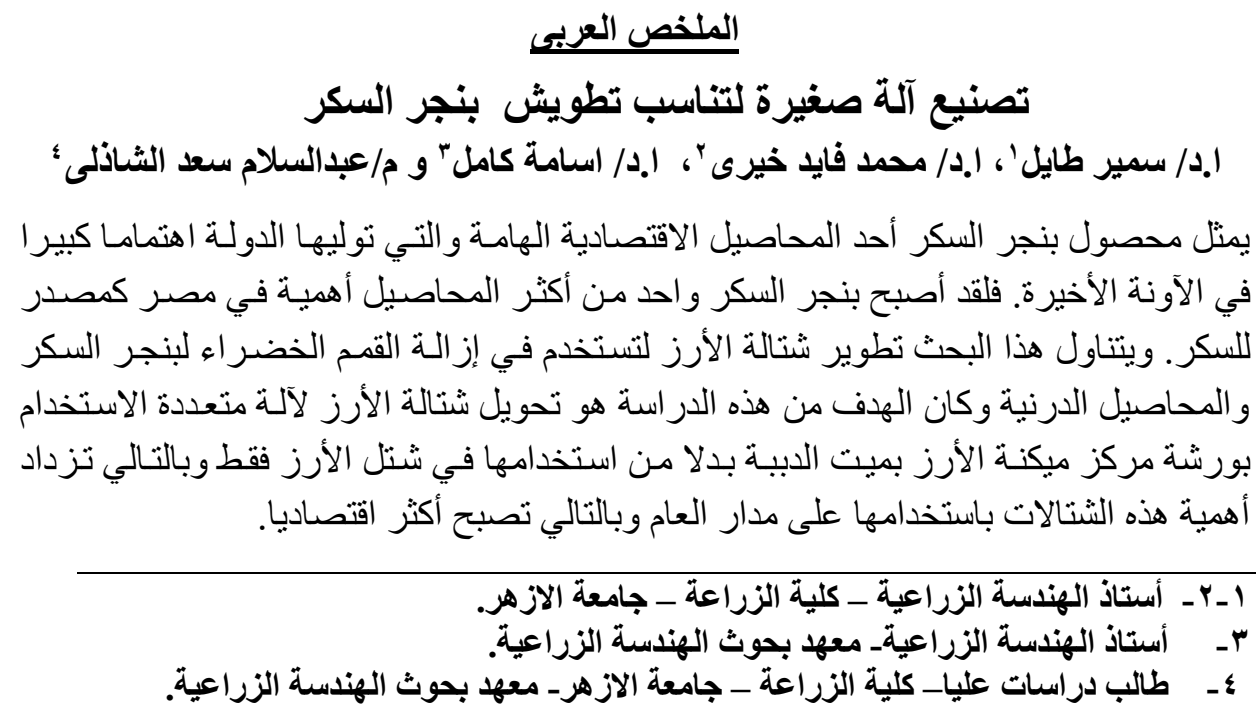




\section{اللهدف من أجراء الدراسة :-}

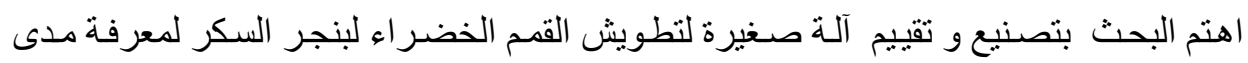

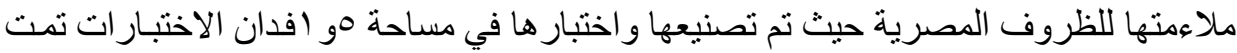
في المعمل والمزر عة البحثية لمركز ميكنة الأرز بميت الديبة ـ محافظة كفر الثيخ أثناء موسـ

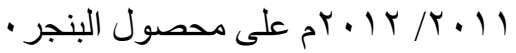

\section{ولقد اشتملث الدراسة على المتغيرات التالية:-}

ا- السرعة الأمامية للآلة ( هو 1 - •و r - مو r كم/ ساعة).

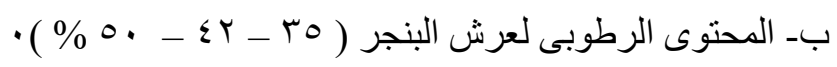

ج- الخلوص بين سكين القطع عن عجله المجس (r - ـ ـ ـ سم)

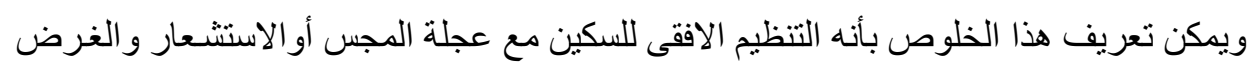

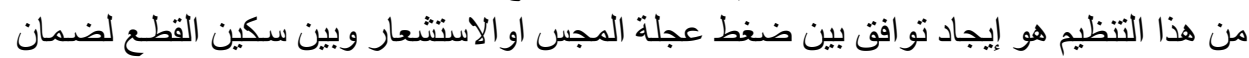

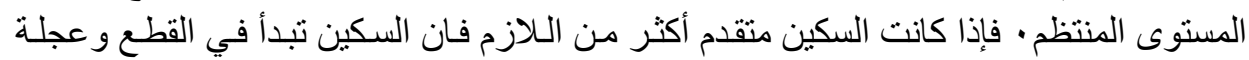
المجس او الاستشعار لم تكن قد مست الر أس مما يسبب دفع الدرنة إلى الإمام وقطعة داخل التربـة

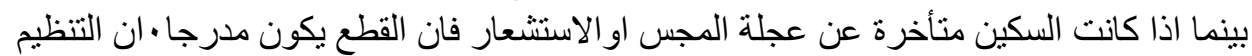
الافقى الصـيح للسكين يكون بعد معرفة مسـاحة قطع رؤوس البنجر من عينـة قليلـة عشو ائية

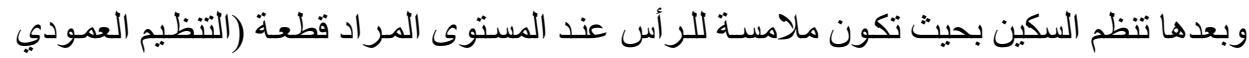

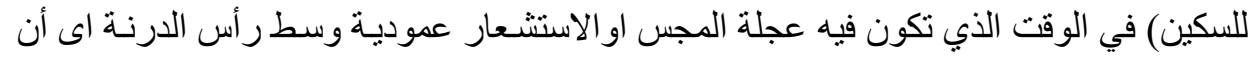

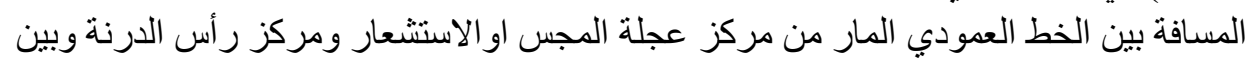

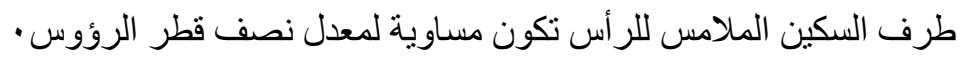

\section{يمكن تلخيص النتائج المتحصل عليها :-}

ا - بزيـادة السر عة الأماميـة لآلة التطويش من هو 1 إلى مو Y كم/سـاعة أدى إلى زيـادة النسبة

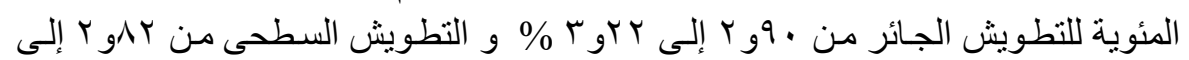

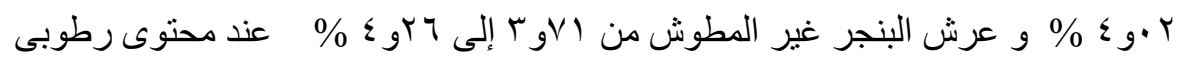

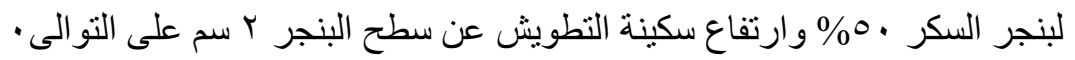

Y - بزيـادة السـر عة الأماميـة لآلـة التطويش من مو ا إلى مو ب كم/سـاعة أدى إلى نقص النسبة

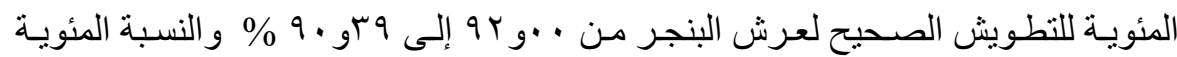

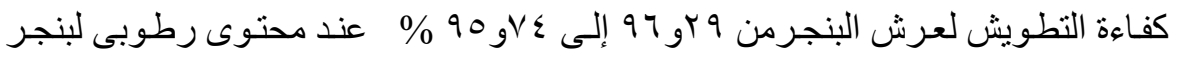

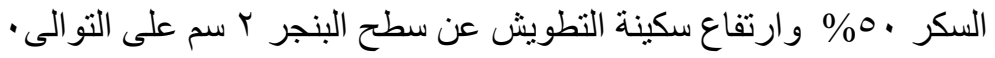

rـ أعلى كفاءة تطويش كانت س بو 9 \% \% سجلت عند الخلوص بين سكينة التطويش عن عجلة

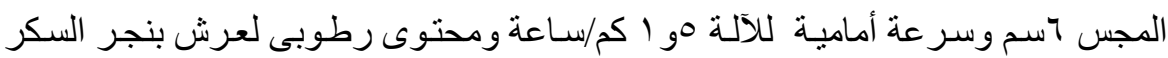

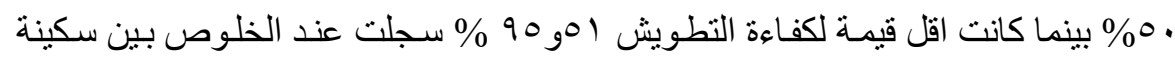




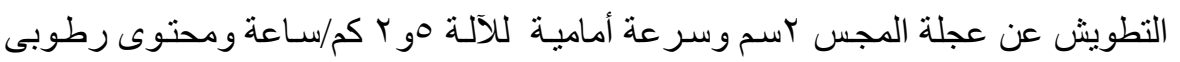

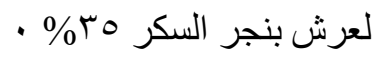

ع- بزيادة السر عة الأمامية للآلة من هو ا إلى مو ب كم/سـاعة أدى ذلك إلى زيـادة السعة الفعلية

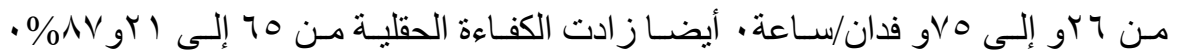

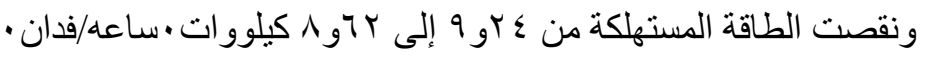

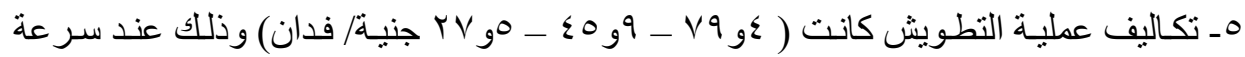

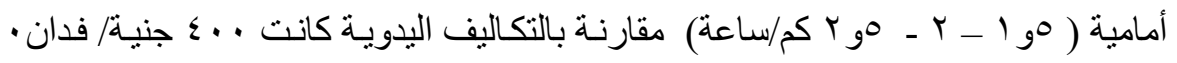
بالتالي فان تكاليف عملية التطويش الميكانيكي سبيت تخفيض مُ شديد من تكاليف التطويش اليدوى 